\title{
Coinfection of diarrheagenic bacterial and viral pathogens in piglets of Northeast region of India
}

\author{
Hosterson Kylla ${ }^{1}$, Tapan K. Dutta², Parimal Roychoudhury² and Prasant K. Subudhi²
}

1. Department of A.H and Veterinary, Disease Investigation Office, Meghalaya, Shillong, India; 2. Department of Veterinary Microbiology, Central Agricultural University, Aizawl, Mizoram, India. Corresponding author: Hosterson Kylla, e-mail: hosterkylla123@yahoo.com

Co-authors: TKD: tapandutta@rediffmail.com, PR: parimal74@rediffmail.com, PKS: subudhipk@gmail.com Received: 15-10-2018, Accepted: 26-12-2018, Published online: 09-02-2019

doi: 10.14202/vetworld.2019.224-230 How to cite this article: Kylla H, Dutta TK, Roychoudhury P, Subudhi PK (2019) Coinfection of diarrheagenic bacterial and viral pathogens in piglets of Northeast region of India, Veterinary World, 12(2): 224-230.

\begin{abstract}
Aim: This study aimed to study the prevalence of the coinfection of enteric bacterial and viral pathogens, namely Escherichia coli, Salmonella, Rotavirus, and Picobirnavirus from fecal samples of pre-weaned piglets in Northeast region of India.
\end{abstract}

Materials and Methods: A total of 457 fresh fecal samples were collected from piglets under 9 weeks old during 2013-2015 from organized $(n=225)$ and unorganized $(n=232)$ farms of Manipur, Meghalaya, Mizoram, and Nagaland. Samples were collected from diarrheic $(n=339)$ and non-diarrheic $(n=118)$ piglets including local indigenous $(n=130)$ and crossbreed $(n=327)$ piglets in different seasons during the study period. The samples were processed for the isolation of E. coli and Salmonella and detection of their putative virulence genes by polymerase chain reaction (PCR). Samples were also processed for the detection of Rotavirus and Picobirnavirus by RNA-polyacrylamide agarose gel electrophoresis and reverse transcriptase-PCR (RT-PCR).

Results: A total of $11(2.40 \%)$ samples were found positive for two or more coinfecting enteric bacterial and viral pathogens. All the 11 positive fecal samples were recovered from diarrheic piglets. Salmonella Typhimurium (enterotoxin, stn gene) and Picobirnavirus genogroup 1 were found to be more frequent as coinfecting agents. Coinfection was recorded higher in unorganized $(3.87 \%)$ compared to organized farm $(0.88 \%)$. Again, higher detection was recorded in crossbreed $(2.75 \%)$ than local indigenous piglets (1.53\%). The occurrence of coinfection was found to be more common during summer (4.68\%) followed by winter $(2.27 \%)$ season.

Conclusion: The present study highlighted the significance of E. coli, Salmonella, Rotavirus, and Picobirnavirus as important diarrheagenic pathogens causing coinfection in piglets in Northeast region of India. Probably, this is the first systematic study of the coinfection of four important diarrheagenic bacterial and viral agents associated with piglet diarrhea in India.

Keywords: coinfection, Escherichia coli, Picobirnavirus, piglets, Rotavirus, Salmonella.

\section{Introduction}

Piggery is a promising venture with vast potential in Northeast region, and the region has the highest pig population in the country with 3.95 million compared to 10.29 million pig population in the whole country [1]. Many swine diseases and ailments affect the productivity particularly pre-weaned piglets, and it was estimated that diarrhea alone accounts for a reduction of 8-14 g/day in average daily weight gain in the $1^{\text {st }}$ week of life [2]. Every year, huge losses in terms of health and productivity are attributed to piglet's diarrhea worldwide. The mechanism of viral and bacterial coinfection contribution to disease augmentation

Copyright: Kylla et al. Open Access. This article is distributed under the terms of the Creative Commons Attribution 4.0 International License (http://creativecommons.org/licenses/by/4.0/), which permits unrestricted use, distribution, and reproduction in any medium, provided you give appropriate credit to the original author(s) and the source, provide a link to the Creative Commons license, and indicate if changes were made. The Creative Commons Public Domain Dedication waiver (http://creativecommons.org/ publicdomain/zero/1.0/) applies to the data made available in this article, unless otherwise stated. was first explained while studying role of secondary bacterial infections during influenza pandemics [3] in which many bacterial agents were associated, but Staphylococcus aureus, Streptococcus pneumoniae, and Haemophilus influenzae are the major bacteria associated in concurrent infection with influenza virus [4]. Researchers have demonstrated that a single susceptible host is attacked and often infected by two or more pathogen species or strains $[5,6]$, in which case coinfecting pathogens may act synergistically, resulting in even greater pathogenesis and such involvement may contribute to the overall disease burden in host species both individually and together in a herd [7]. Such concurrent infections not only augment the clinical course of infections but can also influence host immune responses to pathogens $[8,9]$ and eventually affect the effectiveness of many disease control program in a state or country [10]. Coinfecting pathogens in any species may cause severe diarrhea than infection with a single pathogen alone [11]. Most often concurrent infection with multiple pathogens 
is common particularly among young children with diarrhea and often followed a long severe course and manifestation than infection with a single causal pathogen $[12,13]$.

Infectious diarrhea of neonatal animals is one of the most common and economically devastating conditions encountered in the livestock industry, some of the diarrheas are self-limiting, some are associated with high morbidity, and others are associated with high mortality [14]. Diarrhea remains the second leading cause of death in young children worldwide, accounting for 1.3 million deaths annually and it alone amounts to an estimated $4.1 \%$ of the total global burden of disease $[15,16]$. In food animal species, an array of infectious agents including bacteria, viruses, and parasites cause acute and chronic diarrhea in piglets including Campylobacter spp., Clostridium perfringens, diarrheagenic Escherichia coli, Salmonella, Rotavirus, Coronaviruses (transmissible gastroenteritis virus), porcine epidemic diarrhea virus, as well as by nematode and protozoan parasites $[17,18]$. Such enteric infections lead to gastroenteritis causing life-threatening implication, especially to newborns. Although there are many diarrheagenic pathogens, most studies have been focused only on one pathogen or on few causal agents, as a result, a clear concept of understanding of the relative importance of such causal pathogens and other related factors may have strong biases.

Porcine bacterial and viral enteric pathogens play an important role in terms of zoonoses, drugs resistance, morbidity, and mortality of pigs of different age groups, particularly young pigs, and overall in the hindrance of piggery development program. Only limited work has been carried out in India regarding coinfection of bacterial and viral enteric pathogens. Keeping in view the importance of such pathogens in piglets, the aim of the present research study was to assess the prevalence and molecular characterization of E. coli, Salmonella, Rotavirus, and Picobirnavirus as coinfecting pathogens from piglets of organized and unorganized farms of Manipur, Meghalaya, Mizoram, and Nagaland states of India.

\section{Materials and Methods}

\section{Ethical approval}

The present research work was meant for prevalence study of enteric organisms and no animals were harm during the study. Samples were collected as per standard sample collection procedure.

\section{Collection of fecal samples, animals, and sampling}

A total of 457 fresh fecal samples were collected from piglets under 9 weeks old from organized $(n=225)$ and unorganized $(\mathrm{n}=232)$ farms of four Northeastern Hilly states of India (Figure-1), namely Manipur $(n=108)$, Meghalaya $(n=124)$, Mizoram $(n=120)$, and Nagaland $(\mathrm{n}=105)$. Samples were collected from diarrheic $(n=339)$ and non-diarrheic $(n=118)$ piglets including indigenous local $(\mathrm{n}=130)$ and crossbreed

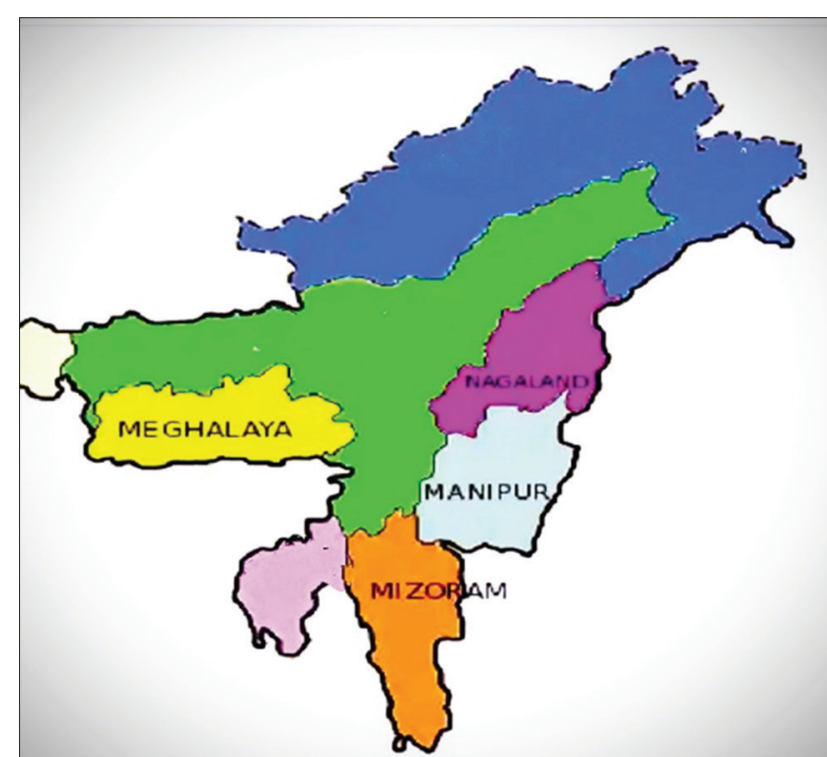

Figure-1: A map representing the four Northeast states of India in which representative sampling were collected for the study. (Source: http:/www.mea.gov.in/india-at-glance.htm)

$(n=327)$ piglets. Samples were collected in four different seasons of the year, namely spring $(\mathrm{n}=93)$, summer $(\mathrm{n}=128)$, autumn $(\mathrm{n}=104)$, and winter $(\mathrm{n}=132)$ during June 2013-May 2015.

Fecal samples were collected and transported to laboratory under cold chain. All the samples were processed for the isolation and identification of E. coli and Salmonella and the detection of enteric viruses including Rotavirus and Picobirnavirus by RNApolyacrylamide agarose gel electrophoresis (PAGE) and reverse transcriptase-polymerase chain reaction (RT-PCR).

\section{Bacteriological screening of clinical specimens}

E. coli and Salmonella were cultured aerobically. For $E$. coli culture, samples were streaked directly on MacConkey agar (HiMedia, India) and characteristic pink-colored colonies were streaked on eosin methylene blue agar plates followed by overnight incubation at $37^{\circ} \mathrm{C}$. Colonies with characteristic metallic sheen were studied for their characteristics. For Salmonella culture, about $2 \mathrm{~g}$ of fecal sample was inoculated in $5 \mathrm{ml}$ Rappaport Vassiliadis broth (HiMedia, India) for enrichment and incubated at $37^{\circ} \mathrm{C}$ for $18-20 \mathrm{~h}$. Culture was then streaked on Xylose lysine deoxycholate agar (HiMedia, India) and incubated at $37^{\circ} \mathrm{C}$ overnight. Typical black centered with bright-edged colonies were selected and streaked on brilliant green agar (BGA) plates. Colonies with pink color on BGA agar were then studied for their characteristics. All the characteristic E. coli and Salmonella isolates were subjected to identification by standard biochemical tests such as indole test, methyl red test, VogesProskauer test, citrate utilization test, and hydrogen sulfide production on triple sugar iron agar [19]. All the pure isolates were stored in glycerol at $-70^{\circ} \mathrm{C}$ for further use. 


\section{Detection of Rotavirus and Picobirnavirus}

The fecal samples were screened for the presence of Rotavirus and Picobirnavirus by RNA-PAGE analysis following standard protocol. In brief, samples were diluted in phosphate-buffered saline $(\mathrm{pH} 7.4)$ to prepare a $10 \%(\mathrm{w} / \mathrm{v})$ fecal suspension. Clarified supernatant was collected and processed for RNA extraction using Trizol method [20]. The extracted RNA was subjected to RNA-PAGE followed by silver staining as per standard procedure [21]. Rotavirus and Picobirnavirus were also detected by RT-PCR. Detection of Rotavirus Groups A and C was performed by targeting VP7 gene [22] and VP6 gene [23], respectively. For the detection of Picobirnavirus genogroup I (GGI) [24] and GGII [25], specific primers were used. Details of oligonucleotides and PCR conditions used in the present study are given in Table-1 [22-29].

\section{Detection of bacterial virulence genes by PCR}

DNA lysate for PCR analysis was prepared by standard boiling and snap chilling method. Detection of the putative virulence genes of enteropathogenic E. coli (EPEC, eaeA), Shiga-toxigenic E. coli (STEC, $\left.s t x_{1}, s_{2} x_{2}\right)$, and enterohemorrhagic E. coli $(h l y A)$ was evaluated by multiplex PCR [26].

In case of Salmonella isolates, the detection of enterotoxin (stn) [27], invasive (invA) [28], and plasmid efficacy fimbrial (pef) [29] genes was carried out by specific PCR assay in a thermal cycler (Eppendorf, Germany). Oligonucleotides and PCR conditions used in the study are depicted in Table-1 [22-29].

\section{Agarose gel electrophoresis}

All amplified products were separated by $1 \%$ agarose gel in $1 \mathrm{X}$ Tris-borate-EDTA buffer by electrophoresis and stained with ethidium bromide $(0.5 \mu \mathrm{g} / \mathrm{ml})$. Standard molecular size marker (100 bp
DNA ladder) was included in each gel. DNA fragments were observed by ultraviolet transilluminator and photographed in a gel documentation system (Alpha Imager, Germany).

\section{Serotyping of isolates}

Salmonella isolates were serotyped at National Salmonella and Escherichia Centre, Kasauli, Himachal Pradesh, India, and the National Salmonella Centre, Indian Veterinary Research Institute, Bareilly, Uttar Pradesh, India.

\section{Results}

Bacterial and viral diarrheagenic pathogens are persistent in livestock population in India. In the present study, samples positive for coinfection with E. coli, Salmonella, Rotavirus A, and Picobirnavirus GG1 were detected from diarrheic fecal samples $(n=339)$ only; whereas, no coinfection of organisms was detected from 118 non-diarrheic fecal samples collected during 2013-15.

A total of $11(2.40 \%)$ fecal samples from Northeast states were found positive for more than one pathogen as depicted in Table-2. Of the overall 11 positive samples, two samples from Manipur were found positive for coinfection of EPEC and Picobirnavirus GG1. In case of coinfection from samples of Meghalaya, a total of five diarrheic samples were found positive for at least two enteric pathogens. One fecal sample was found positive for EPEC and Rotavirus A; two samples were positive for both Salmonella Typhimurium (stn) and Picobirnavirus GGI; one sample was found positive for EPEC and Picobirnavirus GG1, whereas, in one diarrheic sample, three enteric pathogens, namely Picobirnavirus GG1, EPEC, and Salmonella rough strain (stn) were detected harboring associated virulence genes.

Table-1: Oligonucleotide primers used in the present study.

\begin{tabular}{|c|c|c|c|c|}
\hline Primer & Sequences $\left(5^{\prime}-3^{\prime}\right)$ & Annealing temperature & Amplicon size (bp) & References \\
\hline $\begin{array}{l}\text { Rota A } \\
\text { (VP7) }\end{array}$ & $\begin{array}{l}\text { (F) TTGACTAARGGRTGGCCAACWGG } \\
\text { (R) TCGCATCATHCKYTCNGTTTGTGG }\end{array}$ & $55^{\circ} \mathrm{C}$ & 540 & {$[22]$} \\
\hline $\begin{array}{l}\text { Rota C } \\
\text { (VP6) }\end{array}$ & $\begin{array}{l}\text { (F) CTCGATGCTACTACAGAATCAG } \\
\text { (R) AGCCACATAGTTCACATTCATCC }\end{array}$ & $46^{\circ} \mathrm{C}$ & 356 & [23] \\
\hline PBV & $\begin{array}{l}\text { (F) TGGTGTGGATGTTTC } \\
\text { (R) A(G,A)TG(C,T)TGGTCGAACTT }\end{array}$ & $48^{\circ} \mathrm{C}$ & 201 & {$[24]$} \\
\hline $\begin{array}{l}\text { PBV } \\
\text { (GGII) }\end{array}$ & $\begin{array}{l}\text { (F) GACCGGTWTGGATGTTTCCGATG } \\
\text { (R) GTATCTGTGCTGGSCGCAT }\end{array}$ & $56^{\circ} \mathrm{C}$ & 369 & [25] \\
\hline eaeA & $\begin{array}{l}\text { (F) GACCCGGCACAAGCATAAGC } \\
\text { (R) CCACCTGCAGCAACAAGAGG }\end{array}$ & $61^{\circ} \mathrm{C}$ & 384 & {$[26]$} \\
\hline$s t \times 1$ & $\begin{array}{l}\text { (F) ATAAATCGCCATTCGTTGACTAC } \\
\text { (R) AGAACGCCCACTGAGATCATC }\end{array}$ & $61^{\circ} \mathrm{C}$ & 180 & {$[26]$} \\
\hline$s t \times 2$ & $\begin{array}{l}\text { (F) GGCACTGTCTGAAACTGCTCC } \\
\text { (R) TCGCCAGTTAATCTGACATTCTG }\end{array}$ & $61^{\circ} \mathrm{C}$ & 253 & {$[26]$} \\
\hline hlyA & $\begin{array}{l}\text { (F) GCATCATCAAGCGTACGTTCC } \\
\text { (R) AATGAGCCAAGCTGGTTAGCT }\end{array}$ & $61^{\circ} \mathrm{C}$ & 534 & {$[26]$} \\
\hline stn & $\begin{array}{l}\text { (F) TTGTGTCGCTATCACTGGCAACC } \\
\text { (R) ATTCGTAACCCGCTCTCGTCC }\end{array}$ & $61^{\circ} \mathrm{C}$ & 617 & {$[27]$} \\
\hline invA & $\begin{array}{l}\text { (F) ACCACGCTCTTTCGTCTGG } \\
\text { (R) GAACTGACTACGTAGACGCTC }\end{array}$ & $60^{\circ} \mathrm{C}$ & 941 & {$[28]$} \\
\hline pef & $\begin{array}{l}\text { (F) TGTTCCGGGCTTGTGCT } \\
\text { (R) CAGGGCATTTGCTGATTCTTCC }\end{array}$ & $57^{\circ} \mathrm{C}$ & 700 & [29] \\
\hline
\end{tabular}

GG1=Genogroup 1, GGII=Genogroup II 
In Mizoram, a total of three samples were positive for coinfection with at least two pathogens. One diarrheic sample was found positive for STEC ( $s t x_{2}$ gene), $S$. Typhimurium (invasive, invA gene), and Picobirnavirus GG1; and two diarrheic fecal samples were found positive for both $S$. Typhimurium $(s t n)$ and Picobirnavirus GG1. However, in diarrheic samples from piglets of Nagaland, only one sample was found positive for $S$. Typhimurium (stn) and STEC ( $\left.s t x_{2}\right)$.

Among the pathogens under study, coinfection with either Picobirnavirus GG1 was found to be more frequent $(\mathrm{n}=8)$. In all the positive samples with Picobirnavirus GG1 were found as coinfective with enteric bacterial pathogens either EPEC, STEC, or Salmonella. However, Rotavirus type A (RVA) was detected only in one diarrheic sample as coinfection with EPEC. Five diarrheic samples were found to be coinfective of EPEC with other infectious agents, namely Salmonella, RVA, and Picobirnavirus GG1. Shigatoxigenic E. coli STEC (stx, gene) were detected as coinfective strain with Salmonella and Picobirnavirus GG1 in two diarrheic samples under the study. Again, seven diarrheic samples from North Eastern states were found to be positive for Salmonella spp. as one of the coinfective agents with other enteric pathogens, in which the most frequent Salmonella serotype involved was Typhimurium (Table-2).

In total, $9(3.87 \%)$ samples harboring pathogens involved as coinfection in piglets was detected from unorganized farms, whereas only $2(0.88 \%)$ samples were from organized farms. Again, of the 11 positive samples, crossbreed piglets recorded higher detection of mixed infection $(9 ; 2.75 \%)$ than local indigenous piglets $(2 ; 1.53 \%)$. The samples in the present study were collected during different seasons of the year. The occurrence of coinfection was found to be most common during summer season $(n=6 ; 4.68 \%)$, followed by winter $(n=3 ; 2.27 \%)$, spring $(n=1 ; 1.07 \%)$, and autumn $(\mathrm{n}=1 ; 0.96 \%)$, respectively.

\section{Discussion}

In our study, coinfection of at least two infectious pathogens is recorded in $2.4 \%$, whereas higher prevalence was recorded by other researchers. In a study by Mesonero-Escuredo et al. [30] recorded that $43.1 \%$ of samples were positive for more than one pathogen either bacterial or viral pathogens in pig neonatal diarrhea cases in Spain with $C$. perfringens type A being involve in all cases. However, Katsuda et al. [31] noted that infectious diarrhea in newborn piglets is usually related to the presence of a single pathogen and mixed infections are considered less common. In another study by Zhang et al. [32] recorded $4.3 \%$ of positive cooccurrences of enteric pathogens in sick children in Southwest China where E. coli and Norovirus were the predominant coinfective pathogens. These reports suggested that coinfection of pathogens varies from one region to another geographical region. Neonatal diarrhea, particularly in young piglets, is often complex with a mixture of infectious agents and other factors such as passive immunity transferred by colostrum and milk, environmental temperature and humidity [33,34], and managemental factor [35], all contributing to its manifestation.

In the present study, Picobirnavirus GG1 was recorded as highest cases as coinfecting agent. Picobirnaviruses are generally regarded as diarrheagenic viruses because most of their detection is associated with virus shed in feces and have been detected in animals and human patients with and without gastroenteritis and mostly coinfected with other enteric viruses such as Rotavirus, Astrovirus, Calicivirus, and Coronavirus [36,37].

Many researchers [38-41] reported that RVA is the most common cause of viral diarrhea in neonatal pigs compared to Type $\mathrm{C}$, and other workers have detected porcine Rotavirus in diarrheic fecal samples in nursing, weaning, and post-weaning pigs either alone or in combination of other enteric pathogens such as E. coli, Salmonella, and Adenovirus [42,43]. Rotavirus A is only often detected as the sole infectious agent than as coinfection in cases of neonatal diarrhea [31,44]. This is in agreement with our finding in which RVA was detected only in one diarrheic sample as coinfection with EPEC. Although it is clear that RVA has an overwhelming impact on diarrhea illnesses in children, coinfection with other enteric pathogens appears to aggravate diarrhea severity. These findings should serve as evidence for public health services when planning and developing intervention programs [32].

Table-2: Coinfection of enteric bacterial and viral pathogens in diarrheic fecal samples.

\begin{tabular}{|c|c|c|}
\hline State & Samples positive for $>1$ gene & Coinfecting pathogens with associated genes \\
\hline Manipur & $\mathrm{n}=2$ & E. coli $($ eaeA)+Picobirnavirus GG1 \\
\hline \multirow[t]{4}{*}{ Meghalaya } & $\mathrm{n}=1$ & E. coli $($ eaeA)+Rotavirus A \\
\hline & $\mathrm{n}=1$ & E. coli $($ eaeA)+S. rough $($ stn $)+$ Picobirnavirus GG1 \\
\hline & $\mathrm{n}=2$ & S. Typhimurium (stn)+Picobirnavirus GG1 \\
\hline & $\mathrm{n}=1$ & E. coli (eaeA)+Picobirnavirus GG1 \\
\hline \multirow[t]{2}{*}{ Mizoram } & $\mathrm{n}=1$ & S. Typhimurium $($ invA $)+E$. coli $\left(\right.$ st $\left.\times_{2}\right)+$ Picobirnavirus GG1 \\
\hline & $\mathrm{n}=2$ & S. Typhimurium (stn)+Picobirnavirus GG1 \\
\hline Nagaland & $\mathrm{n}=1$ & S. Hiduddify $(s t n)+E$. coli $\left(\right.$ st $\left.\times_{2}\right)$ \\
\hline Total & $\mathrm{n}=11$ & \\
\hline
\end{tabular}

GG1=Genogroup 1, S. Typhimurium=Salmonella Typhimurium, E. coli=Escherichia coli 
Diarrheagenic E. coli are important common bacterial pathogen involve in piglets diarrhea. According to Fairbrother and Gyles [33], the main pathotype of $E$. coli responsible for intestinal disease in pigs is enterotoxigenic E. coli and EPEC also known as attaching and effacing $E$. coli. Coinfection of EPEC with other infectious agents indicates that EPEC potentially accelerates gastroenteritis and is one of the main pathogens involved in coinfection with other diarrheagenic bacterial or viral pathogens. Shiga-toxigenic $E$. coli was detected as coinfective strain in two diarrheic samples. The strain is one of the leading causes of diarrhea in the developing world and importantly in Northeast India, and they are commonly recovered from diarrheic feces of food-producing animals including porcine $[45,46]$.

Salmonellosis is one of the economically important enteric and septicemic diseases associated with morbidity and even mortality in farm animals [47]. In our study, $S$. Typhimurium was the most frequent serovar involved in coinfection; however, this serovar is not host-specific serovar in pigs; hence, the finding is an indication of a public health and zoonotic concern. The close monitoring of such concurrent infection in porcine is important not only in terms of production but also from a public health point of view.

In the present study, higher detection of coinfection was recorded from unorganized farms, compared to organized farms. The reason for variation probably might be due to different management being practice from farm to farm, particularly in case of Picobirnaviruses which can enter and transmit mainly through sewage and untreated water in the farm [48]. Crossbreed piglets recorded higher detection of mixed infection than local indigenous piglets. Although the variation is not very significant, it may be possible that the local non-descriptive piglets possess better immunity against natural infection than crossbreed animals. In addition, the weaning age of piglets of the local animals is generally $8-10$ weeks in comparison with the crossbreed animals in organized farms (within 6 weeks). Maternal immunity might also play an important role in resisting the infection in piglets, particularly in indigenous pigs. In the same region in a study of diarrheagenic pathogens, reported a higher prevalence rate of Picobirnavirus and STEC in crossbreed than indigenous piglets population $[24,46]$. In our study, samples collected during different seasons showed that coinfection of enteric pathogens was found to be most common during the summer (June-August). However, due to paucity of reports regarding seasonal variation of coinfection, hence, this did not allow us to compare our results. The humid climatic condition during summer with persistent rainfall in Northeast region may be an important reason for entry and transmission of infection among the pig population. Such climatic condition also allows suitable environment for persistent enteric pathogens such as $E$. coli,
Salmonella, Rotavirus, and Picobirnavirus to cause diarrhea in piglets.

Diarrhea or scour has been recognized as one of the most common ailments causing deaths of young animals including piglets, but it is very often a neglected problem in most farming system. In the present study, a total of 11 diarrheic fecal samples were detected for a combination of at least two different enteric pathogens which are suggestive of the fact that a number of enteric pathogens may cause diarrhea either singly or in combination. Considering the importance of E. coli, Salmonella, Rotavirus, and Picobirnavirus as important diarrheal causing agents in animal species and human, hence, there is a possibility of transmission between porcine and human population, particularly in rural tribal areas in North East Hilly region of India were people reared two or three pigs in close proximity with human habitation and most share common drinking water.

\section{Conclusion}

Only limited work has been carried out in India about coinfection of diarrheagenic bacterial and viral agents in porcine. Hence, the present study provides updated information and highlighted the significance of E. coli, Salmonella, Rotavirus, and Picobirnavirus as important diarrheagenic pathogens causing coinfection in piglets, where such data are scarce. In conclusion, it may be stated that coinfections with either of the four enteric bacterial and viral pathogens persist and associated with the piglet diarrhea in Northeast region of India, particularly with Picobirnavirus and $S$. Typhimurium. Higher prevalence is recorded from unorganized compared to organized farm and higher detection in crossbreed compared to the local indigenous pigs with higher detection during the summer season. This probably the first systematic study of the prevalence of the coinfection of important diarrheagenic bacterial and viral pathogens associated with piglet diarrhea in India.

\section{Authors' Contributions}

TKD and HK designed and planned the research work. HK collected the samples and executed the isolation, biochemical, and molecular characterization work and carried out the antibiotic sensitivity assay of all isolates. HK, TK, PR, and PKS analyzed the data and monitored the results and assay. All authors contributed equally in the preparation and revision of the manuscript. All authors read and approved the final manuscript.

\section{Acknowledgments}

The authors are highly thankful to the Department of Biotechnology, Government of India for funding the study (Grant No. DBT-NER/LIVS/11/2012, dated 24/04/2014), and the Dean, College of Veterinary Sciences and Animal Husbandry, Selesih, Mizoram, for providing all the facilities to carry out the research work. 


\section{Competing Interests}

The authors declare that they have no competing interests.

\section{Publisher's Note}

Veterinary World remains neutral with regard to jurisdictional claims in published map and institutional affiliation.

\section{References}

1. Livestock Census. (2012) Department of Animal Husbandry and Dairying, Ministry of Agriculture. Government of India, New Delhi.

2. Kongsted, H., Stege, H., Toft, N. and Nielsen, J.P. (2014) The effect of new neonatal porcine diarrhea syndrome (NNPDS) on average daily gain and mortality in four Danish pig herds. BMC Vet. Res., 10(1): 90.

3. Klein, E.Y., Monteforte, B., Gupta, A., Jiang, W., May, L., Hsieh, Y.H. and Dugas, A. (2016) The frequency of influenza and bacterial coinfection: A systematic review and meta-analysis. Influenza Other Respir. Viruses, 10(5): 394-403.

4. Martin-Loeches, I., van Someren Greve, F. and Schultz, M.J. (2017) Bacterial pneumonia as an influenza complication. Curr. Opin. Infect. Dis., 30(2): 201-207.

5. Seppala, O., Karvonen, A., Rellstab, C., Louhi, K.R. and Jokela, J. (2012) Reciprocal interaction matrix reveals complex genetic and dose-dependent specificity among co-infecting parasites. Am. Nat., 180(3): 306-315.

6. Susi, H., Barres, B., Vale, P.F. and Laine, A.L. (2015) Co-infection alters population dynamics of infectious disease. Nat. Commun., 6: 5975.

7. O'Ryan, M., Prado, V. and Pickering, L.K. (2005) A millennium update on pediatric diarrheal illness in the developing world. Semin. Pediatr. Infect. Dis., 16(2): 125-136.

8. Cox, F.E. (2001) Concomitant infections, parasites and immune responses. Parasitology, 122: S23-38.

9. Read, A.F. and Taylor, L.H. (2001) The ecology of genetically diverse infections. Science, 292(5519): 1099-1102.

10. Li, X.X. and Zhou, X.N. (2013) Co-infection of tuberculosis and parasitic diseases in humans: A systematic review. Parasit. Vectors, 6(1): 79.

11. Grimprel, E., Rodrigo, C. and Desselberger, U. (2008) Rotavirus disease: Impact of coinfections. Pediatr. Infect. Dis. J., 27(1): S3-S10.

12. Bonkoungou, I.J., Haukka, K., Osterblad, M., Hakanen, A.J., Traore, A.S., Barro, N. and Siitonen, A. (2013) Bacterial and viral etiology of childhood diarrhea in Ouagadougou, Burkina Faso. BMC. Pediatr., 13(1): 36.

13. Bhavnani, D., Goldstick, J.E., Cevallos, W., Trueba, G. and Eisenberg, J.N. (2012) Synergistic effects between Rotavirus and coinfecting pathogens on diarrheal disease: Evidence from a community-based study in northwestern Ecuador. Am. J. Epidemiol., 176(5): 387-395.

14. Holland, R.E. (1990) Some infectious causes of diarrhea in young farm animals. Clin. Microbiol. Rev., 3(4): 345-375.

15. Black, R.E., Cousens, S., Johnson, H.L., Lawn, J.E., Rudan, I., Bassani, D.G., Jha, P., Campbell, H., Walker, C.F., Cibulskis, R., Eisele, T., Liu, L. and Mathers, C. (2010) Global, regional, and national causes of child mortality in 2008: A systematic analysis. Lancet, 375(9730): 1969-1987.

16. Das, J.K., Salam, R.A. and Bhutta, Z.A. (2014) Global burden of childhood diarrhea and interventions. Curr. Opin. Infect. Dis., 27(5): 451-458.

17. Snodgrass, D.R., Terzolo, H.R., Campbell, D., Sherwood, I., Menzies, J.D. and Synge, B.A. (1986) Aetiology of diarrhea in young calves. Vet. Rec., 119(2): 31-34.

18. Zimmerman, J.J., Karriker, L.A., Ramirez, A., Schwartz, K.J. and Stevenson, G.W. (2012) Diseases of Swine. $10^{\text {th }}$ ed. Wiley, New York.
19. Ewing, W.H. (1986) Edward and Ewing's Identification of Enterobacteriaceae. $4^{\text {th }}$ ed. Elsevier, New York. p1-536.

20. World Health Organization. (2009) Manual of Rotavirus Detection and Characterization Methods. World Health Organization Manual, Geneva, Switzerland.

21. Herring, A.J., Inglis, N.F., Ojeh, C.K., Snodgrass, D.R. and Menzies, J.D. (1982) Rapid diagnosis of Rotavirus infection by direct detection of viral nucleic acid in silver-stained polyacrylamide gels. J. Clin. Microbiol., 16(3): 473-477.

22. Kylla, H. (2015) Detection and Molecular Characterization of Enteric Bacterial and Viral Pathogens of Piglets in North Eastern States (Manipur, Meghalaya, Mizoram and Nagaland) of India. Ph. D Thesis Submitted to the Central Agricultural University, Imphal, Manipur (India).

23. Gabbay, Y.B., Borges, A.A., Oliveria, D.S., Linhares, A.C., Mascarenhas, J.D., Barardi, C.R., Simoes, C.M., Wang, Y., Glass, R.I. and Jiang, B. (2008) Evidence for zoonotic transmission of group C Rotaviruses among children in Belem, Brazil. J. Med. Virol., 80(9): 1666-1674.

24. Kylla, H., Dutta., T.K., Roychoudhury, P., Malik., Y.S., Mandakini, R. and Subudhi, P.K. (2017) Prevalence and molecular characterization of porcine Picobirnavirus in piglets of North East region of India. Trop. Anim. Health. Prod., 49(2): 417-422.

25. Smits, S.L., Poon, L.M.M., Van Leeuwen, M., Lau, P.N., Parera, H.K.K., Peiris, J.S.M., Simon, J.H. and Osterhaus, A.D.M. (2011) Genogroup I and II Picobirnaviruses in respiratory tracts of pigs. Emerg. Infect. Dis., 17(12): 2328-2330.

26. Paton, J.C. and Paton, A.W. (1998) Pathogenesis and diagnosis of Shiga-toxin producing Escherichia coli infections. Clin. Microbiol. Rev., 11(3): 450-479.

27. Prager, R., Fruth, A. and Tschape, H. (1995) Salmonella enterotoxin $(s t n)$ gene is prevalent among strains of Salmonella Enterica but not among Salmonella Bongori and other Enterobacteriaceae. FEMS Immunol. Med. Microbiol., 12(1): 47-50.

28. Galan, J.E., Ginocchio, C., Costeas, P. (1992) Molecular and functional characterization of the Salmonella gene invA: homology of invA to members of a new protein family. J. Bacteriol., 174(13): 4338-4349.

29. Rahman, H., Prager, R. and Tschape, H. (2000) Occurrence of sef and pef genes among different serovars of Salmonella. Ind. J. Med. Res., 111: 40-42.

30. Mesonero-Escuredo, S., Strutzberg-Minder, K., Casanovas, C. and Segalés, J. (2018) Viral and bacterial investigations on the etiology of recurrent pig neonatal diarrhea cases in Spain. Porcine. Health. Manag., 4: 5.

31. Katsuda, K., Kohmoto, M., Kawashima, K. and Tsunemitsu, H. (2006) Frequency of enteropathogen detection in suckling and weaned pigs with diarrhea in Japan. $J$. Vet. Diagn. Investig., 18(4): 350-354.

32. Zhang, S.X., Zhou, Y.M., Xu, W., Tian, L.G., Chen, J.X., Chen, S.H., Dang, Z.S., Gu, W.P., Yin, J.W., Serrano, E. and Zhou, X.N. (2016) Impact of co-infections with enteric pathogens on children suffering from acute diarrhea in southwest China. Infect. Dis. Poverty, 5(1): 64.

33. Fairbrother, J.M. and Gyles, C.L. (2012) Colibacillosis. In: Zimmerman, J., Karriker, L.A., Ramirez, A., Schwartz, K.J. and Stevenson, G.W. Diseases of Swine. $10^{\text {th }}$ ed. WileyBlackwell, Chichester. p723-749.

34. Pedersen, L.J., Malmkvist, J., Kammersgaard, T. and Jorgensen, E. (2013) Avoiding hypothermia in neonatal pigs: Effect of duration of floor heating at different room temperatures. J. Anim. Sci., 91(1): 425-432.

35. Martineau, G.P., Vaillancourt, J.P. and Broes, A. (1995) Principal neonatal diseases. In: Varley, M.A., editor. The Neonatal Pig Development and Survival. CAB International, Wallingford. p239-264.

36. Malik, Y.S., Kumar, N., Sharma, K., Dhama, K., Shabbir, M.Z., Ganesh, B., Kobayashi, N. and Banyai, K. (2014) Epidemiology, phylogeny and evolution of emerging enteric Picobirnaviruses of animal origin and their relationship to human strains. Biomed. Res. Int., 2014: 1-13. 
37. Banyai, K., Jakab, F., Reuter, G., Bene, J., Melegh, B. and Szucs, G. (2003) Sequence heterogeneity among human Picobirnaviruses detected in a gastroenteritis outbreak. Arch. Virol., 148(1): 2281-2291.

38. Vlasova, A.N., Amimo, J.O. and Saif, L.J. (2017) Porcine Rotaviruses: Epidemiology, immune responses and control strategies. Viruses, 9(3): 48.

39. Theuns, S., Vyt, P., Desmarets, L.M.B., Roukaerts, I.D.M., Heylen, E., Zeller, M., Matthijnssens, J. and Nauwynck, H.J. (2016) Presence and characterization of pig group A and C Rotaviruses in feces of Belgian diarrheic suckling piglets. Virus Res., 213(1): 172-183.

40. Marthaler, D., Homwong, N., Rossow, K., Culhane, M., Goyal, S., Collins, J., Matthijnssens, J. and Ciarlet, M. (2014) Rapid detection and high occurrence of porcine rotavirus $\mathrm{A}, \mathrm{B}$, and $\mathrm{C}$ by $\mathrm{RT}-\mathrm{qPCR}$ in diagnostic samples. J. Virol. Methods, 209: 30-34.

41. Kylla, H., Dutta, T.K., Roychoudhury, P., Mandakini, R. and Subudhi, P.K. (2018) Detection and characterization of genogroup 5 Rotavirus associated with piglet diarrhea in the North East region of India. Vet. Arch., 88(4): 453-466.

42. Kim, Y., Chang, K.O., Straw, B. and Saif, L.J. (1999) Characterization of group C Rotaviruses associated with diarrhea outbreak in feeder pigs. J. Clin. Microbiol., 37(5): 1484-1488.

43. Martella, V., Banyai, K. and Lorusso, E. (2007) Prevalence of group C Rotaviruses in weaning and post-weaning pigs with enteritis. Vet. Microbiol., 123(1-3): 26-33.

44. Chan, G., Farzan, A., DeLay, J., McEwen, B., Prescott, J.F. and Friendship, R.M. (2013) A retrospective study on the etiological diagnoses of diarrhea in neonatal piglets in Ontario, Canada, between 2001 and 2010. Can. J. Vet. Res., 77(4): 254-260.

45. Nataro, J.P. and Kaper, J.B. (1998) Diarrhoeagenic Escherichia coli. Clin. Microbiol. Rev., 11(2): 142-201.

46. Kylla, H., Dutta, T.K. and Kawlni, L. (2017) Prevalence and molecular characterization of shigatoxigenic Escherichia coli in piglets of North East region of India. Int. J. Trop. Dis. Health, 27(2): 1-8.

47. Malkawi, H.I. and Gharaibeh, R. (2004) Rapid and simultaneous identification of two Salmonella Enterica serotypes Enteritidis and Typhimurium from chicken and meat product by multiplex PCR. Biotechnology, 3(1): 44-48.

48. Symonds, E.M., Griffin, D.W. and Breitbart, M. (2009) Eukaryotic viruses in wastewater samples from the United States. Appl. Environ. Microbiol., 75(5): 1402-1409. 